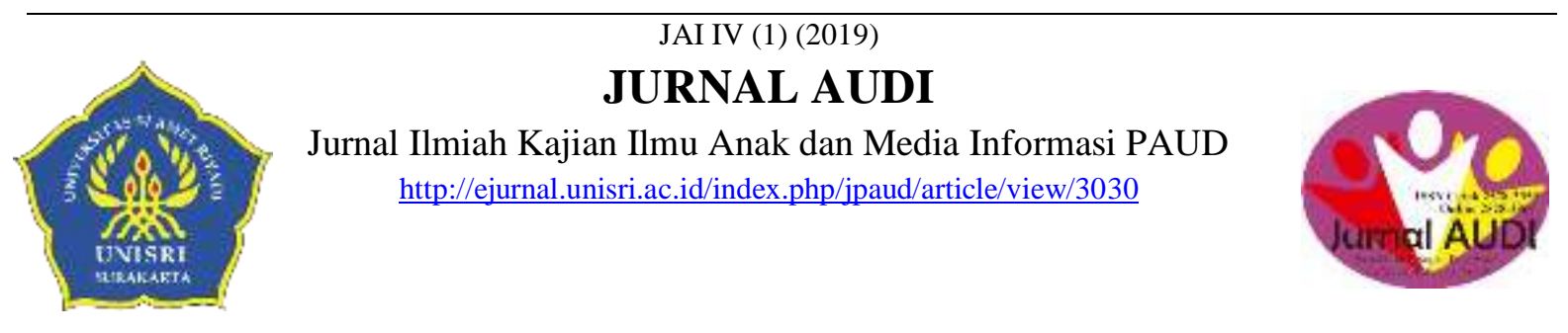

\title{
MODEL PEMBELAJARAN TARI NUSANTARA : SEBUAH CONTOH KREATIVITAS MODEL TARI PIRING BAGI GURU PAUD
}

\author{
Fifiet Dwi Tresna Santana1, Ifat Fatimah Zahro \\ . PG PAUD STKIP Siliwangi Bandung
}

\section{Info Artikel}

Sejarah Artikel:

Diterima Juni 2019

Disetujui Juni 2019

Dipublikasikan Juni

2019

\section{Keywords:}

Models Of Learning,

Creativity,

Archipelago Dance,

Early Childhood

Education.

\begin{abstract}
Abstrak
Tujuan penulisan ini adalah konsep dan model pembelajaran tari kreatif dalam rangka mengembangkan kreativitas tari peserta didik Pendidikan Anak Usia Dini (PAUD). Melalui penelitian ini juga diharapkan menemukan teori pembelajaran yang berlandaskan data empirik di lapangan. Fokus masalah dalam penelitian ini yakni: 1). Keterbatasan pengetahuan tentang bagaimana membuat sebuah kreativitas tari Nusantara di PAUD; 2). Terbatasnya guru dalam mengolah seni tari Nusantara sebagai bahan ajar bagi anak usia dini; 3). Keterbatasan kemampuan guru dalam mengajarkan seni tari Nusantara kepada peserta didik PAUD. Metode yang digunakan dalam mencapai tujuan tersebut adalah dengan menggunakan metode penelitian kualitatif dengan studi kasus terhadap guru-guru PAUD di lingkungan Kota Cimahi. Observasi, wawancara, serta dokumentasi akan dilakukan untuk mendapatkan data mengenai konsep dan strategi pembelajaran, bahan ajar, pendekatan-pendekatan pembelajaran, evaluasi, media, dan sumber belajar PAUD. Hasil dari penelitian ini adalah peningkatan kompetensi pedagogik dan profesional guru dalam pembelajaran seni tari dan model pembelajaran tari nusantara dengan sebuah contoh kreativitas tari piring.
\end{abstract}

Abstract

The purpose of this writing is the concept and model of creative dance learning in order to develop the dance creativity of Early Childhood Education (PAUD) students. Through this research, it is also expected to find learning theories based on empirical data in the field. The focus of the problem in this study is: 1). Limited knowledge about how to create a Nusantara dance creativity in PAUD; 2). The limited teacher in processing Nusantara dance art as teaching material for early childhood; 3). The limited ability of teachers to teach Nusantara dance to PAUD students. The method used in achieving these objectives is to use qualitative research methods with case studies of PAUD teachers in the Cimahi City environment. Observations, interviews, and documentation will be carried out to obtain data on learning concepts and strategies, teaching materials, learning approaches, evaluation, media, and PAUD learning resources. The results of this study were an increase in the pedagogical and professional competence of teachers in learning dance and the archipelago dance learning model with an example of plate dance creativity.

(C) 2019 FKIP Universitas Slamet Riyadi

\begin{tabular}{lr}
\hline Alamat korespondensi: Jl. Terusan Jendral Sudirman, & ISSN 2528-3359 (Print) \\
Cimahi & ISSN 2528-3367(Online)
\end{tabular}

E-mail: fifiet@ikipsiliwangi.ac.id 


\section{PENDAHULUAN}

Saat ini, berbagai upaya yang dilakukan pemerintah untuk peningkatan kualitas pendidikan di Indonesia seperti tertera dalam dalam Undang-undang Republik Indonesia nomor 20 tahun 2003 tentang Sistem Pendidikan Nasional adalah membantu dan memfasilitasi pengembangan potensi anak bangsa secara utuh sejak usia dini sampai akhir hayat. Termasuk tentang layanan pendidikan anak usia dini, terdapat dalam UU No. 23 Tahun 2002 Pasal 9 Ayat 1 tentang Perlindungan anak dinyatakan bahwa "Setiap anak berhak memperoleh pendidikan dan pengajaran dalam rangka pengembangan pribadinya dan tingkat kecerdasannya sesuai dengan minat dan bakatnya". Selain itu, pada kurikulum tahun 2004 terdapat pembelajaran seni dan budaya termasuk seni tari yang dilakukan pada tingkat Pendidikan Anak Usia Dini (PAUD), bahkan pada peserta didik yang berkebutuhan khusus dengan tujuan untuk mewujudkan potensi yang terdapat dalam diri peserta didik.

Oleh karena itu, PAUD memberi kesempatan kepada anak untuk mengembangkan kepribadian dan potensi secara maksimal, yakni lembaga PAUD perlu menyediakan berbagai kegiatan yang dapat mengembangkan berbagai aspek perkembangan seperti: spiritual, kognitif, bahasa, sosial, emosi, fisik motorik dan seni. Berkaitan dengan hal tersebut, bahwa pembelajaran seni tari di sekolah sangat penting dikarenakan proses pembelajaran seni tari berperan untuk membantu peserta didik dalam mengoptimalkan perkembangan aspek kognitif, afektif serta motorik melalui kegiatan kreatif. Melalui aktivitas seni tari, anak dapat mengekspresikan ide kreatifnya. Karena pembelajaran seni tari sebenarnya tidak hanya mengajarkan anak tentang bagaimana gerakan tari saja, tetapi pendidikan seni tari dapat dijadikan sebagai media penanaman nilai-nilai kehidupan kepada anak sedini mungkin juga mengembangkan berbagai dimensi kecerdasan dan perkembangan anak.

Terdapat beberapa kendala yang dihadapkan pada proses pembelajaran seni tari: Pertama, peserta didik terkesan kurang termotivasi melakukan gerak akibat materi ajar yang sangat sulit, mengingat materi ajar langsung pada bentuk gerak tari yang rumit. Bentuk gerak yang rumit diperlukan latihan secara khusus dan memerlukan waktu berlatih, akibatnya tujuan pembelajaran menjadi tidak tercapai dengan baik. Kedua, adanya persepsi dari peserta didik, bahwa seni tari hanya pantas dilakukan oleh peserta didik perempuan, akibatnya peserta didik laki-laki menjadi enggan untuk mengikuti pembelajaran. Faktor tersebut telah mengakibatkan pembelajaran seni tari menjadi kurang perhatian dari anak laki-laki. Padahal pembelajaran seni tari diperuntukkan untuk semua peserta didik. Ketiga, adanya persepsi bahwa pembelajaran tari terfokus pada bentuk gerak yang indah, maka tersedianya ruangan yang memadai serta fasilitas yang harus lengkap, akibatnya pembelajaran seni tari tidak dapat terselenggara. Keempat, guru dalam menginterpretasikan kurikulum kurang komprehensif, akibatnya pembelajaran seni tari menjadi kurang sesuai dengan tujuan. Interkasi pembelajaran cenderung satu arah, kurang variatif, dan terkesan monoton. Permasalahan ini muncul dikarenakan beberapa hal sebagai berikut: 1). Keterbatasan pengetahuan tentang bagaimana membuat sebuah kreativitas tari Nusantara di PAUD; 2). Terbatasnya guru dalam mengolah seni tari Nusantara sebagai bahan ajar bagi anak usia dini; 3). Keterbatasan kemampuan guru dalam mengajarkan seni tari Nusantara kepada peserta didik PAUD. Keterbatasan dikhawatirkan menyebabkan tujuan dari pembelajaran (learning goal) tidak tercapai. Apabila hal ini terus menerus dibiarkan, maka akan terbentuk siswa yang pasif yang hanya menerima pembelajaran bukan menjadi generasi yang aktif sesuai dengan perkembangan jaman saat ini.

Tujuan penulisan ini untuk: 1) Menggambarkan konsep, strategi, bahan ajar, pendekatan, evaluasi, dan media yang digunakan guru PAUD, khususnya di Pos PAUD Melati 06 Kota Cimahi dan RA Baitussalam Cimahi; 2) Mengidentifikasi 
cara guru dalam mengembangkan ide dan gagasannya dalam mengeksplorasi tari Piring di Pos PAUD Melati 06 Kota Cimahi dan RA Baitussalam Cimahi; 3) Mengenalkan satu model tari Piring sebagai salah satu model pembelajaran tari nusantara di lembaga-lembaga PAUD.

\section{KAJIAN TEORI}

Pendidikan seni tari anak usia dini adalah suatu proses atau usaha dalam mendidik anak agar mampu mengontrol dan menginterpretasikan gerak tubuh, memanipulasi benda-benda dan menumbuhkan harmoni antara tubuh dan pikiran. Menutut (Rohmah 2013) Tari merupakan gerakan yang ritmis, gerak yang bersifat nonrepresentative, yaitu gerak yang tidak menggambarkanapapun kecuali semata-mata hanya mengandalkan kemampuan dari tubuh dalam menerjemahkan pola ruang dan waktunya yang khas. Gerakan lazim yang disebut dengan gerak murni. Sehingga pendidikan seni tari pada anak usia dini menekankan pada gerak, keharmonisan gerak, mengontrol gerak motorik kasar maupun motorik halus yang dapat mengembangkan kecerdasan anak (Mulyani, 2016: 68)

Konsep seni tari di sekolah, pada proses pembelajaran tari kreatif, konsep ini seharusnya ada dan memiliki pengaruh dalam pembelajaran seni tari. Tari kreatif membantu perkembangan kognitif, afektif, physikal dan sosial (Gilbert, 2002). Memvisualisasikan ide dan gagasan dalam bentuk gerak melalui tubuh merupakan pijakan dasar dalam mempersiapkan penciptaan seni tari. Guru bertindak sebagai pembimbing dapat memberikan beberapa stimulus musikal untuk didengarkan dan dipilih oleh peserta didik. Peserta didik dapat mengemukakan ide-ide dan gagasannya dalam menciptakan gerak untuk divisualisasikan.

Konsep seni musik di sekolah, terdapat aspek musik yang keduanya saling menunjang mewujudkan sebuah keterpaduan. Musik adalah sebuah fenomena seni yang memakai medium bunyi, sedangkan tari adalah fenomena seni yang memakai medium gerak. Kombinasi antara musik dan tari membantu membangkitkan kesempurnaan yang artistik dan menggerakan reaksi kegairahan estetik yang merupakan bagian dari kegiatan menari.

Kasing (2006) menyatakan bahwa 'the languange of dance is movement, the instrument is the human body'. Pernyataan ini dapat diartikan bahwa bahasa tari adalah gerak yang menggunakan badan manusia sebagai instrumennya. Unsur musik yang dapat diasumsikan pengertiannya dalam gerak tari adalah pulsa/ketukan dasar, metrik/arsis-tesis, tempo, durasi/nilai ketukan, birama dinamika, melodi, ritme, bentuk dan lain-lain. Musik dapat menjadi stimulus dengan berdasarkan pemahaman aspek unsur-unsur musikal. Don Campbel (2001) mengatakan bahwa musik mampu menghibur jiwa, menjernihkan pikiran, dan membuat kita lebih cerdas. Medium musik dapat menggerakan, menggungah, dan memberi tenaga bahkan musik dapat menumbuhkan kreativitas dan kecerdasan.

Tujuan yang paling mendasar dari pendidikan seni tari adalah membantu anak melalui tari, untuk menemukan hubungan antara tubuhnya dengan seluruh eksistensinya sebagai manusia. Melalui penekanan kreativitas, anak diberi kesempatan yang seluas-luasnya di dalam proses pengungkapan gerak tarinya, sehingga hasil akhir bukanlah merupakan tujuan utama, tapi bagaimana anak mampu untuk bergerak sesuai dengan kreativitasnya masing-masing.

Imajinasi anak Pendidikan Anak Usia Dini (PAUD) lebih kepada sosial dengan teman-temannya, kreativitas muncul berdasarkan daya imajinasinya itu dan kita sebagai guru harus mendorongnya agar lebih banyak lagi yang dapat diungkapkan peserta didik PAUD melalui daya imajinasinya. Untuk tingkat peserta didik PAUD, pengembangan imajinasi disesuaikan dengan pemahaman dan perkembangan cara berpikir.

Tari dalam pendidikan menekankan kreativitas dan kebebasan ekspresi (Kraus, 1969). Eksplorasi merupakan suatu persyaratan yang penting, hal ini dapat 
diwujudkan dengan adanya komunikasi yang aman antara guru dan peserta didik. Kenyamanan psikologis peserta didik juga penting untuk menumbuhkan tindakan kreatif.

Peran guru untuk menstimulus peserta didik agar dapat menuangkan serta mengembangkan ekspresi gerak yang kreatif baik secara individual maupun kelompok. Ide atau gagasan anak biasanya orisinil, misalnya anak dapat distimulus untuk memberikan contoh dan ide gerak tentang bagaimana menggunakan piring, memutar, berguling dengan menggunakan piring. Guru adalah fasilitator, maka dibiarkan anak memvisualisasikan semua gerakan yang diinginkannya, selanjutnya guru dapat memilih gerakan mana yang penting dan mana yang tidak.

Dalam pembelajaran seni anak usia dini, pengalaman belajar mencipta seni disebut sebagai pembelajaran berkarya. Pembelajaran berkarya seni mengandung dua aspek kompetensi, yaitu keterampilan dan kreativitas. Keterampilan lebih difokuskan pada pengalaman eksplorasi untuk melatih kemampuan sensorik dan motorik anak. Kreativitas meliputi ranah kognitif, afektif dan psikomotorik yang terlihat dari hasil karya dan proses dalam menyibukkan diri secara kreatif.

Idealnya, bahan atau materi yang disajikan dalam kegiatan kreatif, menjadikan anak-anak pencipta gerak tari. Dalam hal ini guru harus mampu memupuk dan menumbuhkan daya kreatif anak-anak untuk menemukan gerakan baru.

Kreativitas tari di sekolah, menurut Mary Joyce (1993) mengemukakan bahwa anak-anak menemukan kekayaan besar tentang badan, perasaan, bahasa, pikiranpikiran, imajinasi, dan ide-ide melalui tari kreatif. Anak akan belajar apa yang badan dapat lakukan dan menghubungkannya dengan kekuatan-kekuatan yang mereka miliki. Pengalaman tari ini mengajarkan anak kesadaran dengan kontrol gerak. Selanjutnya, Joyce juga mengatakan bahwa gerakan sebagai ekspresi kreatif memainkan peranan penting dalam kehidupan, membangun self-image, self-awarness, dan self-direction. Kesadaran akan self merupakan keseluruhan seorang anak secara utuh. Berdasarkan pendapat Joyce inilah maka kreativitas tari menjadi penting dalam perkembangan anak.

Kemampuan untuk mencipta dan langkah-langkah dari kegiatan kreatif mulai lahir dari kegiatan-kegiatan yang bersumber dari rangsangan atau dorongan (motivasi) sehingga timbul kemampuan dalam mengeksplorasikannya. Kemudian, hasil eksplorasi diproyeksikan untuk menjadi sesuatu yang baru, baik wujud baru itu bertolak dari bahan atau materi yang lama (sudah ada) atau mempergunakan materi yang baru.

Kreativitas diartikan sebagai 'kemampuan untuk menciptakan produkproduk baru yang mempunyai makna sosial, kemampuan untuk merumuskan kombinasi baru dari dua konsep atau lebih yang ada di alam pikiran' (Joyce. 1993). Kreavitas memberikan suatu tuntunan utama yang menjadikan ciri tingkah laku orang-orang kreatif untuk diketahui oleh penata tari adalah orisinalitas, keingintahuan dan kecerdikan, fasih dalam ide-ide dan imageimage, keterlibatan, motivasi dan penghayatan, kepekaan, cita rasa, dan kekuatan melawan bentuk-bentuk klise, kemampuan membedakan dan memilih serta keberanian untuk menolak yang tidak penting.

Dengan demikian, kegiatan kreatif dalam seni tari, adalah di satu sisi menciptakan yang baru atau mengadakan inovasi, namun di pihak lain juga memberikan interpretasi kepada bentukbentuk kreasi lama. Dalam mengembangkan kreativitas anak, menurut Didi Suryanto selaku praktisi tari (Mulyani, 2016:98) bahwa gerakan kreatif anak tergantung dari pengalaman anak ketika berinteraksi dengan lingkungan dan sejauh mana anak mampu berfikir untuk mengungkapkan gagasan atau perasaan mereka dalam sebuah gerakan, sehingga diperlukan suatu komunikasi yang dapat memberikan kesempatan bagi anak untuk mengungkapkan ekspresi-ekspresi gerak secara wajar. Pengalaman bereksplorasi tersebut sangat memungkinkan 
anak-anak untuk menemukan sesuatu yang menarik, sehingga ia dapat mengetahui bagaimana bergerak dan mengembangkan kemampuan dalam membuat gerakan.

Hal yang paling utama dalam pembelajaran seni tari adalah rasa senang pada anak. Menentukan materi pembelajaran seni tari bagi anak usia dini tidaklah mudah, sehingga dibutuhkan pengetahuan dan kecermatan dari guru tari dalam memilih materi pembelajaran seni tari yang sesuai dengan karakter dasar dan kebutuhan anak, yang pada akhirnya dapat memberikan rangsangan, arahan, motivasi, dan kreativitas. Tidak semua jenis tari cocok dan relevan dengan dunia anak, oleh karena itu setiap materi gerakan tari yang disampaikan haruslah membuat anak nyaman, senang, dan semangat (ekspresif), untuk menghindari tingkat kesulitan, kebosanan pada anak, serta menumbuhkan rasa percaya diri pada anak.

Sementara itu, dalam menyampaikan materi gerakan tari, guru tari sebaiknya tidak sekaligus memberikan materi gerakan pada anak secara keseluruhan, akan tetapi dengan cara bertahap. Dengan demikian, anak bisa lebih cepat dalam menghafal gerakan tari.

Aspek kreativitas dalam seni tari, yang diutamakan adalah kemampuan anak dalam suatu proses atau cara berfikir yang menghasilkan sesuatu yang baru dan berbeda. Karena dalam hal ini adalah belajar seni tari, maka sisi kreativitasnya adalah bagaimana anak menemukan atau menciptakan gerakan-gerakan yang baru tentang sesuatu, yang sesuai dengan apa yang mereka pikirkan dan rasakan.

Menurut Purnomo (2013), pembelajaran kreatif dalam seni tari mencakup aspek: eksplorasi, improvisasi, inkubasi dan hasil. Hal serupa dijelaskan Hawkin (1990) mengenai gerak tari yaitu ada empat tahap kreatif yaitu :

\section{Eksplorasi}

yaitu pengalaman melakukan penjajakan gerak, untuk menghasilkan ragam gerak. Pada kegiatan ini berupa imajinasi melakukan interpretasi terhadap apa yang telah dilihat, didengar, atau diraba. Siswa dapat bebas bergerak mengikuti kata hatinya, mengikuti imajinasi dan interpretasinya.

2. Improvisasi

yaitu pengalaman secara spontanitas mencoba-coba atau mencari-cari kemungkinan ragam gerak yang telah diperoleh pada waktu eksplorasi. Dari setiap ragam gerak yang dihasilkan pada waktu eksplorasi, dikembangkan dari aspek tenaga, ruang dan waktu sehingga menghasilkan ragam gerak yang sangat banyak.

3. Evaluasi

yaitu pengalaman untuk menilai dan menyeleksi ragam gerak yang telah dihasilkan pada tahap improvisasi. Dalam kegiatan ini siswa mulai menyeleksi dengan cara membuat ragam gerak yang tidak sesuai dan memilih ragam gerak yang sesuai dengan gagasannya. Hasil inilah yang akan digarap oleh siswa pada tahap komposisi tari.

4. Komposisi

yaitu tujuan akhir manusia untuk memberikan bentuk terhadap apa yang siswa temukan.

\section{METODE}

Penelitian ini menggunakan penelitian kualitatif karena terfokus kepada pembelajaran seni tari yang mengembangkan kreativitas tari. Adapun metode yang digunakan secara spesifik adalah studi kasus. Penelitian ini akan melibatkan konteks dan peneliti yang ingin lebih memahami bagaimana guru-guru Pendidikan Anak Usia Dini (PAUD) di Kota Cimahi mengembangkan kreativitas tari Nusantara melalui tari Piring dan bagaimana peserta didik berkreasi. Penelitian ini akan dilakukan di sekitar kota Cimahi, dengan subjek utamanya guru dan peserta didik PAUD. Teknik pengumpulan data melalui beberapa cara diantaranya: observasi pada pembelajaran seni tari, wawancara dengan guru dan peserta didik, perekaman dengan audio dan video serta studi dokumentasi.

Observasi, wawancara, dan studi dokumentasi akan dilakukan selama satu semester pada masa aktif sekolah, sedangkan 
analisis dan penulisan laporan akan dilakukan pada semester kedua. Proses analisis data akan dilakukan secara triangulasi data-data hasil observasi, wawancara, dan studi dokumentasi. Sehingga hasil analisis ini dapat menghasilkan sebuah konsep tari kreatif di Kota Cimahi dan model pembelajaran seni tari nusantara yang mendorong kreativitas peserta didik di sekolah. Model pembelajaran ini akan dijadikan bahan ajar untuk guru-guru seni di Indonesia.

Penelitian ini dilakukan di Lembagalembaga PAUD yang diselenggarakan di Kota Cimahi. Subjek penelitian ini adalah semua anak-anak usia 4-6 tahun yang berjumlah 12 orang dan guru-guru yang berjumlah 4 orang.

Lokasi yang dijadikan objek dalam penelitian ini adalah terdiri dari 2 tempat, yaitu:

1. Pos PAUD Melati 06 yang terletak di Jln. Panembakan Utara No. 95A Rt. 05/Rw.06 Kel. Padasuka Kota Cimahi. Yang menjadi sumber data adalah pihak pengelola, guru, dan anak.

2. RA Baitussalam yang terletak di Jln. Pojok Selatan 1 Rt. 02/Rw. 07 Kota Cimahi. Yang menjadi sumber data adalah pihak pengelola, guru, dan anak.

Oleh karena penelitian kualitatif bertujuan memahami secara mendalam dan terfokus, maka sampelnya bersifat purposif . Nana Syaodih (2007:101) menjelaskan sampel purposif ini memfokuskan pada informan-informan terpilih yang kaya dengan kasus untuk studi yang bersifat mendalam. Kekuatan dari sampel purposif adalah dari sedikit kasus yang diteliti secara mendalam memberikan banyak pemahaman tentang topik. Menurut Sugiyono (2009:300), teknik sampling yang digunakan adalah purposive sampling, yaitu teknik pengambilan sampel sumber data dengan pertimbangan tertentu dan snowball sampling yaitu teknik pengambilan sampel sumber data, yang awalnya jumlahnya sedikit akan semakin besar.
Sesuai dengan fokus penelitian, pemilihan lokasi dan sumber data terkait dengan judul penelitian ini didasarkan sebagai berikut:

1. Kegiatan ekstrakulikuler di Pos PAUD Melati 06 dan RA Baitussalam adalah seni tari, yang dilaksanakan seminggu satu kali. Sehingga kegiatan rutin ini merupakan program tahunan yang dicapai untuk acara pentas seni di akhir tahun ajaran dan lomba antar lembaga.

2. POS PAUD Melati 06 dan RA Baitussalam dipilih karena menunjukkan adanya guru yang ahli dalam tari nusantara dan memiliki kreativitas tari. Hal ini dibuktikan dengan kejuaraan tarian anak usia dini dan mendapatkan penghargaan baik tingkat kota maupun provinsi.

\section{HASIL DAN PEMBAHASAN}

\section{Pembelajaran Seni Tari di Pos PAUD Melati 06 dan RA. Baitussalam Cimahi}

Pos PAUD Melati 06 dipilih sebagai lokasi sampel aplikasi dalam penelitian, memiliki keunggulan dibandingkan dengan sekolah lainnya. Sekolah ini sering kali mengikuti lomba-lomba tari baik di sekolah (internal) maupun di luar sekolah (eksternal). Kegiatan seni tari dilaksanakan setiap hari kamis. Para guru dan siswa melakukan kegiatan rutin ini sudah sejak lama (Wawancara dengan kepala sekolah, 2017). Para siswa dan guru sangat antusias sekali mengikuti proses pembelajaran yang dilakukan. Selain itu siswa pada hari kamis menggunakan pakaian hijau yang menandakan adanya semangat dan kebersamaan dalam melakukan aktivitas menari. Setiap semester guru mencari bahan ajar seni tari yang dapat diaplikasikan di sekolah. Salah satu contoh saja pada tahun 2016 siswa belajar tari Maumere, tari-tari yang bertema seperti : tari kelinci, tari kijang, dan lain-lain. Berikut ini adalah piala-piala atau salah satu bukti bahwa tingginya minat terhadap pembelajaran seni tari. Dalam perencanaan model 
pembelajaran tari piring, langkah awal yang dilakukan guru adalah membuat desain model pembelajaran. Tahap selanjutnya yaitu menentukan langkah atau tahapan yang akan diaplikasikan dalam proses belajar mengajar.

Lokasi kedua yang dipilih yaitu RA Baitusalam yang berlokasi di jalan Pojok Selatan 1 RT 02 RW VII Kelurahan Setiamanah Kecamatan Cimahi Tengah Kota Cimahi berbatasan dengan Kompleks TNIAD. Potensi anak usia dini di daerah tersebut cukup banyak serta kesadaran orang tua untuk memasukkan anaknya sejak usia dini cukup tinggi. Lokasi RA Baitussalam sangat strategis jauh dari keramaian sehingga membuat kegiatan belajar dan pembelajaran dapat berjalan dengan kondusif. Dilihat dari data peserta didik jumlahnya cukup tinggi, berimbang antara peserta didik yang berasal dari penduduk setempat dengan peserta didik yang berasal dari kompleks TNI-AD (Profil Sekolah, 2017).

Untuk meningkatkan pelayanan kami terus berbenah dan mengembangkan diri dengan mengikuti pelatihan dan belajar mandiri. Perubahan kami lakukan dari menggunakan pembelajaran klasikal ke kelompok hingga kini menerapkan model sentra (wawancara dengan kepala sekolah, 2017).

Dua lokasi yang berbeda ini tetapi hampir sama dalam mengaplikasikan model tari piring. Banyak gerakan yang tidak terduga/ gerakan hasil kreativitas siswa setelah melihat dari video tari yang ditayangkan. Siswa rata-rata memahami gerakan dan menyesuaikan gerakan yang satu dengan gerakan yang lainnya. Selama ini guru tidak dibekali ilmu dalam membuat sebuah tarian. Biasanya guru-guru melakukan tari hanya demonstrasi saja kemudian siswa mengikuti di belakangnya. Sehingga tidak ada interaksi di dalamnya, setelah adanya kegiatan workshop dan pendampingan guru-guru ternyata lebih mudah mengaplikasikan sebuah tarian. Bahkan guru-guru PAUD lebih kreatif dibandingkan sebelumnya.

\section{Kreativitas Tari Piring Sebagai Model Pembelajaran Tari di PAUD}

Tari piring merupakan tari yang berkelompok dan diiringi oleh musik, dan waktu menari kurang lebih 5 menit. Selain itu dalam tari piring juga memiliki berbagai gerakan yang variatif. Dapat dibuat polapola lantai sebagai perubahan gerak yang satu ke gerak yang lainnya. Tari piring dibuat berdasarkan kreativitasnya sesuai dengan unsur-unsur tari yakni : tenaga, ruang dan waktu. Maka tepatlah jika tari piring digunakan sebagai model pembelajaran tari nusantara di PAUD Cimahi. Gerakan tari piring pada umumnya adalah meletakkan piring ke dalam dua tangan (kanan dan kiri). Sejarah tari piring yaitu merupakan tarian yang sebagai ucapan rasa syukur kepada para dewa atas hasil panen yang berlimpah. Namun seiring dengan perkembangan jaman tari piring ini berubah menjadi sebuah tontonan yang menarik. Hal yang paling unik di dalam tari piring ini yaitu para penari menggunakan kedua tanggan untuk memegang piring. Ini menjadi menarik bagi siswa PAUD khususnya. Dikarenakan siswa pada masa tersebut merupakan masa dimana anak mampu berekeplorasi gerakan sesuai apa yang lihat dan didengar. Kemudian siswa sangat senang dengan adanya properti piring yang berada di atas tangannya.

Dalam hal ini peneliti menjabarkan Syntax model pembelajaran tari Piring dalam pembelajaran seni tari bagi anak usia dini sebagai berikut. 
Tabel 1. Syntax Model Pembelajaran Tari Nusantara/Tari Piring

\begin{tabular}{|l|l|l|}
\hline \multicolumn{2}{|c|}{ SENI BUROK } & \multicolumn{1}{c|}{ KETERANGAN } \\
\hline TAHAP 1 & $\begin{array}{l}\text { Analisis dan interpretasi terhadap } \\
\text { obyek masalah }\end{array}$ & $\begin{array}{l}\text { Pada tahap ini guru menginstruksikan untuk } \\
\text { menganalisis dan menginterpretasikan, } \\
\text { mengapresiasi dan menstimulus melalui } \\
\text { tayangan CD dan property. }\end{array}$ \\
\hline TAHAP 2 & $\begin{array}{l}\text { Pengenalan tari/eksplorasi (gerak, } \\
\text { ruang, waktu dan tenaga) }\end{array}$ & $\begin{array}{l}\text { Pada tahap ini guru mendemonstrasikan } \\
\text { beberapa pengenalan gerak tari imitasi, } \\
\text { siswa bereksplorasi gerak imitasi menurut } \\
\text { peran berdasarkan pengalaman dan } \\
\text { mengekspresikannya } \\
\text { Gerak : ruang gerak, pola lantai, level } \\
\text { Tenaga : kuat, sedang, lemah. }\end{array}$ \\
\hline TAHAP 3 & $\begin{array}{l}\text { Membimbing pelatihan, membuat } \\
\text { kerangka tari piring }\end{array}$ & $\begin{array}{l}\text { Tahap ini, guru merencanakan dan } \\
\text { memberikan bimbingan pelatihan awal, } \\
\text { siswa merangkai gerak imitasi menurut } \\
\text { peran dariawal sampai akhir tarian. }\end{array}$ \\
\hline TAHAP 4 & $\begin{array}{l}\text { Mengecek pemahaman Tari Piring dan } \\
\text { memberikan umpan balik }\end{array}$ & $\begin{array}{l}\text { Pada tahap ini, guru mengecek apakah } \\
\text { siswa telah berhasil melakukan tugas } \\
\text { dengan baik memberi umpan balik. }\end{array}$ \\
\hline TAHAP 5 & Mempergelarkan hasil kreativitas siswa & $\begin{array}{l}\text { Pada tahap ini siswa menampilkan hasil } \\
\text { kreasinya dan guru melakukan pelatihan } \\
\text { lanjutan dengan perhatian khusus pada } \\
\text { penerapan kepada situasi lebih kompleks } \\
\text { dari kehidupan sehari-hari di masyarakat. }\end{array}$ \\
\hline
\end{tabular}

Syntax model pembelajaran tari piring yang dibuat merupakan tahapantahapan pembelajaran. Melalui tahapantahapan ini dapat melihat bagaimana pemahaman siswa terhadap model pembelajaran yang dilakukan oleh guru. Adapun metode pengajaran yang dipergunakan dalam proses belajar mengajar melalui model pembelajaran seni tari adalah sebagai berikut :

1. Metode eksperimen : siswa mencoba untuk menyusun gerakan.

2. Metode latihan : latihan yang dipergunakan untuk proses eksplorasi gerak, melalui rangsang visual dan imajinasi dalam proses penciptaan seni.

3. Metode tanya jawab : untuk merangsang imajinasi kreatif siswa-guru dalam memberikan pertanyaan.

4. Metode diskusi : untuk bertukar pikiran dengan kelompok dalam menyusun sebuah tarian.

5. Metode kreatif : untuk menggali dan meningkatkan daya kreativitas siswa.

Dalam aplikasinya model serta syntax pembelajaran diaplikasikan dalam kurikulum 2013. Adapun standar pada kurikulum 2013 yaitu menekankan pada penguatan kompetensi sikap (belajar mengapa), kompetensi keterampilan (belajar bagaimana), dan kompetensi pengetahuan (belajar apa). Sehingga diharapkan siswa diberikan rangsangan serta kekuatan melalui pengamatan, bertanya, mengolah, menalar dan menyaji. Dalam hal ini sangatlah tepat bilamana siswa diberikan model kreativitas tari nusantara melalui tari piring yang diaplikasikan.

Perlu diketahui penelitian ini didasari dengan adanya di lapangan bahwa guru PAUD selama ini kesulitan dalam mencari bahan ajar serta untuk menampilkan hasil kreasi siswa pada saat kenaikan kelas atau bahkan pada saat lomba. Melalui tulisan ini peneliti mencoba menguraikan dan memandu para guru PAUD untuk dapat menganalisis tari piring, serta membuat sebuah kreativitas tari. Gerakan-gerakan yang ada di dalam tari piring :

Tari piring dibawakan di Sumatera Barat terdiri dari 20 gerakan tari. Namun dalam hal ini yang akan di aplikasikan ke dalam bahan ajar dan model pembelajaran hanyalah gerakan yang sederhana yang dapat dilakukan oleh siswa PAUD. Gerakan tersebut antara lain:

1. Gerakan pembuka, gerakan ini merupakan gerakan sebagai wujud 
rasa ysukur terhadap Tuhan YME, gerakan ini dinamakan dengan istilah gerak pasambahan.

2. Gerakan mencangkul, gerakan ini merupakan gerakan yang menceritakan sekumpulan para petani yang tengah mengolah sawahnya. Dalam bahasa Sumateranya nama gerakan ini dinamai dengan gerakan mencangkul.

3. Gerakan menyiangi, gerakan ini menceritakan aktivitas para petani saat tengah menyiangi atau membersihkan rumput di sawah. Gerakan ini dinamai dengan gerakan menyiang.

4. Gerakan menyemai, gerakan ini menceritakan para petani yang tengah menyemai benih padi yang akan ditanami.

Selanjutnya melakukan workshop dan pendampingan untuk guru PAUD untuk menganalisis tari piring berdasarkan ke empat gerakan yang diberikan yang selanjutnya di modifikasi dengan merubah ruang, tenaga dan waktu sesuai iringan menurut kreativitas masing-masing peserta workshop. Peserta dibagi dengan 5 kelompok, mereka ditugaskan untuk membuat tari berdasarkan hasil eksplorasi gerak tari piring, kemudian mereka memperagakan hasil dengan kelompok masing-masing. Melalui waktu yang singkat para guru PAUD menghasilkan beberapa tari dengan versi yang berbeda sesuai latar belakang mereka dan bentuk tari yang berbeda pula. Respon peserta sangat baik tampak dari hasil eksplorasi, ide kreatif mereka dengan variasi gerak, pola lantai yang mereka kerjakan. Hasil dari pelatihan ini diimplementasikan oleh peserta ke tempat mengajar mereka masing-masing untuk pengembangan selanjutnya. Hal ini akan menghasilkan adanya proses interaktif antara guru - siswa - siswa. Pendapat positif diungkapkan oleh peserta karena mereka dapat berdiskusi, mencatat, mengomentari dan memperagakan hasil eksplorasi dengan empat gerak tari piring, mereka bisa membuat kreativitas tari dengan kelompok masing-masing.
Para peserta workshop melakukan kreasi gerak tari Piring, langkah selanjutnya adalah membuat langkah-langkah pembelajaran yang akan dilaksanakan di kelas. Kemudian diadakan diskusi dan analisis dari hasil kreasi tersebut. Pengalaman berkreasi tari Piring ini kemudian dijadikan perangkat para peserta untuk menyusun bahan ajar dan strategi pembelajaran tari di kelas dengan menggunakan bahan ajar tari Nusantara. Pada tahapan ini peserta diminta untuk membuat laporan tertulis yang meliputi beberapa bagian kegiatan yakni: melakukan analisis bahan ajar tari, kemudian memilih dan menetapkan esensi gerak, setelah itu membuat kreasi gerak tersebut dengan siswa melalui pembelajaran di kelas. Dalam workshop ini yang dijadikan model pembelajaran tari Nusantara adalah pembelajaran tari Piring.

Pada hasil kreativitas ini guru-guru PAUD bukan hanya menampilkan hasil kreativitasnya namun, sudah menampilkan secara utuh tariannya beserta property tari dan busana yang digunakannya. Keunikan dari kelompok ini terlihat dari susunan gerakan serta busana yang dipilih yaitu kekhasan warna dari Melayu yaitu warna kuning dan merah. Selain itu juga, setiap kelompok menampilkan property piring yang digunakan berwarna-warni sehingga dari dua warna tersebut yang siswa termotivasi untuk mengikuti kegiatan pembelajaran tari nusantara.

Pada hasil kreativitas ini guru-guru PAUD bukan hanya menampilkan hasil kreativitasnya namun, sudah menampilkan secara utuh tariannya beserta property tari dan busana yang digunakannya. Keunikan dari kelompok ini terlihat dari susunan gerakan serta busana yang dipilih yaitu kekhasan warna dari Melayu yaitu warna kuning dan merah. Selain itu juga, setiap kelompok menampilkan property piring yang digunakan berwarna-warni sehingga dari dua warna tersebut yang siswa termotivasi untuk mengikuti kegiatan pembelajaran tari nusantara. 
Fifiet Dwi Tresna Santana, Model Pembelajaran Tari Nusantara : Sebuah Contoh Kreativitas Model Tari Piring Bagi Guru PAUD

\section{KESIMPULAN}

Dalam perencanaan model pembelajaran tari piring di Pos PAUD Melati 06 dan RA. Baitussalam Cimahi, melalui langkah-langkah sebagai berikut: 1) Menentukan tujuan pengajaran; 2) Menentukan bahan pengajaran; 3) Guru menentukan beberapa metode pengajaran; 4) Menentukan Syntax model pembelajaran tari piring. Adapun tahapan-tahapannya sebagai berikut : Tahap 1, analisis dan interpretasi terhadap obyek masalah; Tahap 2, pengenalan tari/ekplorasi (gerak, waktu dan tenaga); Tahap 3, membimbing pelatihan, membuat kerangka tari piring; Tahap 4, mengecek pemahaman tari piring dan memberikan feed back.dan Tahap 5, mempergelarkan hasil kreativitas siswa. 5) Menyusun langkah-langkah pembelajaran.

Hasil dari penelitian di POS PAUD Melati 06 dan RA. Baitussalam, bahwa langkah-langkah pembelajaran yang dilaksanakan dalam pembelajaran tari piring. Pada pertemuan pertama yakni pengenalan apresiasi tari piring, dengan tahapan sebagai berikut: a) Gerakan Tari Piring dari berbagai konteks melalui tayangan $\mathrm{CD}$; b) Analisis property tarian; c) Diskusi mengenai gerakan dan tingkat kesulitannya dan d) Siswa menyimak gerakan tersebut. Pada Pertemuan kedua, langkah-langkah pembelajaran yang dilaksanakan dalam pembelajaran tari piring yakni pemahaman tenaga, ruang dan waktu dengan tahapan berikut: pengenalan gerakan tari piring, eksplorasi gerak pengolahan property piring, latihan gerak tari piring, demonstrasi dan pemahaman ruang waktu dan tenaga. Pada pertemuan ketiga dan keempat, langkah-langkah pembelajaran yang dilaksanakan dalam pembelajaran tari piring.dengan tahapan berikut: Apresiasi Gerak Tari Piring, imitasi gerak tari piring yang dicontohkan oleh guru, eksplorasi gerak tari piring, pemahaman gerakan tari piring dan musik, pemahaman waktu, ruang dan tenaga dengan diiringi musik. Pada pertemuan kelima yakni proses penciptaan tari piring dengan tahapan berikut: latihan tampilan kreasi siswa tari piring, gabungan tari dan musik, dan terakhir penampilan hasil kreasi. Pada pertemuan keenam yakni kreasi siswa dengan tahapan pementasan dan evaluasi.

\section{DAFTAR PUSTAKA}

Akdon. (2008). Aplikasi Statistika dan

Metode Penelitian untuk Administrasi

dan Manajemen. Bandung : Dewa

Ruchi.

Arikunto, S .( 2002). Prosedur Suatu

Penelitian : Pendekatan Praktek.

Edisi Revisi Kelima. Jakarta : Rineka

Cipta

--------. (2011). Dasar-dasar Evaluasi

Pendidikan. Jakarta: PT. Bumi

Aksara

Manzilatur Rohmah, A. L. F. I., \& Astini, S. M. (2013). Peran Kegiatan Tari Untuk

Mengembangkan Kemampuan motorik kasar

Anak Kelompok B Di TK Muslimat

Mazraatul Ulum II Paciran

Lamongan. PAUD Teratai, 2(1).

Moleong, J. Lexy. (2007). Metodologi

Penelitian Kualitatif. Bandung:

Rosdakarya

Mulyani Novi. (2016). Pendidikan Seni Tari

Anak Usia Dini. Yogyakarta: Gava

Media.

Sugiyono. (2009). Metode Penelitian

Pendidikan Pendekatan Kuantitatif,

Kualitatif, dan R\&D. Bandung:

Alfabeta

Syaodih-Sukmadinata, N. (2007). Metode

Penelitian Pendidikan. Bandung: PT.

Remaja Rosda Karya 